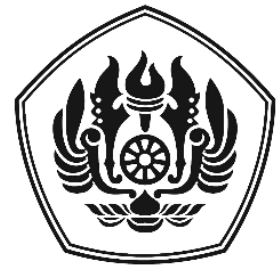

JURNAL

POROS HUKUM

PADJADJARAN

P-ISSN: 2715-7202

E-ISSN: 2715-9418

Artikel diterbitkan:

29 Mei 2020

DOI:

https://doi.org/10.23920/jphp .v1i2.242

Halaman Publikasi:

http://jurnal.fh.unpad.ac.id/i ndex.php/JPHP/issue/archive

Diterbitkan oleh:

Fakultas Hukum

Universitas Padjadjaran

\section{TANGGUNG JAWAB APOTEKER DALAM PELAYANAN OBAT DENGAN RESEP DOKTER}

\section{RESPONSIBILITIES OF PHARMACISTS IN DRUG SERVICE WITH PRESCRIPTION}

\author{
Veronica Komalawatia \\ ABSTRAK
}

Apoteker sebagai tenaga kesehatan profesional di bidang pelayanan kefarmasian dalam menjalankan tugasnya didasarkan kode etik sebagai penjiwaan moral pekerjaan keprofesian. Namun kode etik profesi kadang-kadang sudah tidak begitu diperhatikan lagi. Akibatnya, ciri profesi luhur bidang kefarmasian sebagai pemberian bantuan berupa pelayanan obat yang berorientasi kebutuhan masyarakat, luntur dan cenderung menjadi transaksi komersial produk kefarmasian yang berorientasi keuntungan bisnis. Metode penelitian menggunakan pendekatan yuridis normatif dengan spesifikasi penelitian bersifat deskriptif analitis. Pengumpulan data dilakukan melalui inventarisasi dan penelahaan bahan hukum primer, sekunder, dan tersier yang kemudian dianalisis secara yuridis kualitatif. Tugas dan kewenangan apoteker dalam menjalankan pekerjaan kefarmasian adalah dalam pembuatan termasuk pengendalian mutu sediaan farmasi, pengamanan, pengadaan, penyimpanan dan pendistribusian atau penyaluran obat, pengelolaan obat, pelayanan obat atas resep dokter, pelayanan informasi obat, serta pengembangan obat, bahan obat dan obat tradisional. Tanggung jawab apoteker dalam pelayanan obat yang diresepkan dokter adalah harus mengutamakan kebutuhan dan keselamatan pasien. Tanggung jawab menyeluruh apoteker dalam pelayanan obat adalah kepedulian farmasi untuk meningkatkan mutu kehidupan pasien.

Kata kunci: pelayanan obat; tanggung jawab apoteker; resep dokter.

\begin{abstract}
Pharmacist as a professional health worker in the field of pharmacy services in carrying out its duties is based on the code of Ethics as a moral psychiatric profession work. But a profession code of ethics is sometimes not very much noticed. Consequently, the hallmark of the noble profession of pharmacy as a provision of assistance in the form of drug services oriented to community needs, wear off and tend to be commercial transactions of pharmaceutical products that are business-oriented. The research method uses a normative juridical approach with research specifications of the analytical descriptive. Data collection is conducted through the inventory and study of primary, secondary, and tertiary legal materials which are then analyzed in a qualitative juridical. The duty and authority of the pharmacist in carrying out the work of the pharmacy is in the manufacture including the quality control of
\end{abstract} a Fakultas Hukum Universitas Padjadjaran, Jalan Raya Bandung-Sumedang KM.21 Jatinangor Kab. Sumedang, email:
veronica@unpad.ac.id. 
pharmaceutical preparations, securing, procurement, storage and distribution of drugs, drug management, medical treatment of Doctor's prescription, drug information services, and the development of medicines, medicinal materials and traditional medicines. The responsibility of the pharmacist in the drug service prescribed by the Doctor is to prioritize the needs and safety of patients. The overall responsibility of pharmacists in drug service is pharmaceutical care to improve the quality of patient life.

Keywords: drug services; medical prescription; pharmacist's responsibilities.

\section{PENDAHULUAN}

Kesehatan merupakan modal utama yang memungkinkan setiap orang hidup produktif secara sosial ekonomis. Oleh karena itu semua upaya kesehatan untuk memelihara dan meningkatkan kesehatan baik yang dilakukan oleh pemerintah maupun masyarakat sangat diperlukan. Hal ini tidak terlepas pula dari tanggng jawab setiap orang untuk ikut serta dalam memelihara dan meningkatkan derajat kesehatan perorangan, keluarga, dan masyarakat.

Itulah sebabnya, seiring dengan perkembangan tekonologi dan cara berpikir manusia, arti kesehatan juga sudah berubah. Kesehatan bukan hanya sekedar tidak sakit dan dapat menjalankan tugas dan kewajiban sehari-hari, melainkan juga meliputi kesehatan jiwa dan sosial. Dengan demikian, yang dimaksud dengan kemampuan manusia untuk dapat hidup sehat adalah kemampuan untuk memenuhi kebutuhan hidupnya, baik kebutuhan material maupun kebutuhan spiritual.

Sehubungan dengan itu, Organisasi Kesehatan Dunia (WHO) telah merumuskan batasan pengertian kesehatan sebagai keadaan yang baik secara fisik, mental, maupun sosial, tidak menunjukkan gejala sakit, mempunyai daya tahan yang kuat terhadap gejolak yang terjadi setiap harinya. Selain itu, di dalam pasal 1 ayat 1 Undang - Undang No. 36 Tahun 2009 Tentang Kesehatan juga dirumuskan, bahwa kesehatan adalah keadaan sehat, baik secara fisik, mental, spritual maupun sosial yang memungkinkan setiap orang untuk hidup produktif secara sosial dan ekonomis.

Guna terselenggaranya upaya kesehatan yang dibutuhkan oleh masyarakat, maka diperlukan sumber daya kesehatan sebagai pendukung, antara lain: tenaga kesehatan, misalnya: dokter, dokter gigi dan apoteker dan sarana kesehatan, misalnya: rumah sakit, praktik dokter, praktik dokter gigi dan apotek.

Oleh karena upaya kesehatan itu sendiri dapat berupa upaya kesehatan dasar, rujukan, dan atau penunjang, maka sarana kesehatan dapat berfungsi untuk melaksanakan ketiga jenis upaya tersebut. Itulah sebabnya, dalam upaya meningkatkan derajat kesehatan masyarakat, pemerintah terus berusaha dalam menyelenggarakan 
serta menggiatkan baik usaha di bidang pelayanan kesehatan pokok ataupun sarana penunjangnya, antara lain apotek. Dengan semakin berkembangnya pelayanan kesehatan dan sarana penunjangnya, maka kebutuhan akan tenaga kesehatan antara lain dokter dan apoteker juga semakin meningkat.

Secara umum, dokter memberikan pelayanan kesehatan sebagai upaya yang diselenggarakan baik perseorangan maupun bersama - sama dalam suatu lembaga yang ditujukan terhadap perseorangan ataupun masyarakat. Sedangkan apoteker memberikan pelayanan obat atau kefarmasian sebagai salah satu bagian dari pelayanan kesehatan baik yang diselenggarakan oleh pemerintah ataupun swasta, yaitu antara lain dengan mendirikan apotek.

Salah satu tugas apoteker dalam melakukan praktik kefarmasian, yaitu pelayanan resep. Dalam pelayanan resep tersebut terdapat problematika yang telah lama terjadi dan secara terus menerus yaitu tulisan resep yang sulit dibaca, ketidaklengkapan administrasi resep sebagai informasi pengobatan pasien (legalitas). ${ }^{1}$

Akan tetapi, jenis obat yang beredar di masyarakat semakin bertambah banyak, maka apoteker sebagai tenaga profesional dalam memberikan pelayanan obat sangat besar peranannya, terutama di dalam penyelenggaraan apotek. Sebab tugas seorang apoteker selain memberikan pelayanan resep dari dokter juga harus memberikan informasi yang benar tentang obat di apotek. Apoteker dalam menjalankan profesinya bertanggung jawab penuh atas tindakan - tindakan kefarmasian melalui instrumen instrumen terukur berupa standar prosedur operasional yang ditetapkan untuk dilaksanakan bersama tim tenaga kefarmasian yang berada dalam tanggung jawabnya. ${ }^{2}$

Untuk itu pemerintah telah menerbitkan PP No. 51 Tahun 2009 Tentang Pekerjaan Kefarmasian yang merupakan bagian dari usaha pemerintah untuk memeratakan dan memperluas pelayanan kesehatan kepada masyarakat dari penggunaan obat yang salah, atau penyalahgunaan obat, atau penggunaan obat yang tidak sesuai dengan resep dokter. Selain itu, penggunaan obat juga bukan hanya mengandung khasiat untuk menghilangkan dan menyembuhkan penyakit, tetapi juga dapat menimbulkan kerugian apabila digunakan secara salah, disalahgunakan pemakaiannya, atau digunakan tidak sesuai dengan resep dokter. Dengan demikian, ternyata di dalam pelayanan resep obat

\footnotetext{
1 Wendi Muh. Fadli, et.al., (2016). Tanggungjawab Hukum Dokter dan Apoteker dalam Pelayanan Resep, Media Farmasi, Vol. 13, No. 1, Maret Tahun 2016, hlm. 62-63.

2 Ali Mashuda, (2012). Paradigma dan Tatanan Baru Praktik Kefarmasian, Bandung: Tiga Maha, hlm. 2.
} 
atau resep dokter di apotek timbul hubungan hukum antara berbagai pihak yang terlibat, antara lain: pasien selaku konsumen obat, apoteker, dan dokter. Oleh sebab itu diperlukan suatu penelitian untuk mengetahui dan memahami tugas dan kewenangan apoteker dalam menjalankan pekerjaan kefarmasian di apotek didasarkan peraturan hukum di bidang kesehatan, serta untuk menentukan dan merumuskan aspek hukum tanggung jawab apoteker dalam pelayanan obat yang diresepkan dokter.

\section{PEMBAHASAN}

\section{Tugas dan Kewenangan Apoteker}

Didasarkan Peraturan Pemerintah No. 51 Tahun 2009 Tentang Pekerjaan Kefarmasian, Tenaga Kefarmasian terdiri dari Apoteker dan Tenaga Teknis Kefarmasian. Yang dimaksud dengan apoteker adalah sarjana farmasi yang telah lulus sebagai apoteker dan telah mengucapkan sumpah jabatan apoteker, yang artinya apoteker adalah seseorang yang berdasarkan peraturan perundang-undangan yang berlaku, berhak melakukan pekerjaan kefarmasian di Indonesia. Sedangkan Tenaga Teknis Kefarmasian (TTK) adalah tenaga yang membantu Apoteker dalam menjalankan pekerjaan kefarmasian, yang terdiri atas Sarjana Farmasi, Ahli Madya Farmasi, Analis Farmasi, dan Tenaga Menengah Farmasi/Asisten Apoteker.

Selanjutnya, menurut peraturan tersebut bahwa yang dimaksud dengan pekerjaan kefarmasian adalah pembuatan termasuk pengendalian mutu sediaan farmasi, pengamanan, pengadaan, penyimpanan dan pendistribusi atau penyaluran obat, pengelolaan obat, pelayanan obat atas resep dokter, pelayanan informasi obat, serta pengembangan obat, bahan obat dan obat tradisional. Salah satu tempat dilakukannya pekerjaan kefarmasian dan pelayanan obat atas resep dokter kepada masyarakat adalah apotek.

Didasarkan kedua pengertian di atas, maka jelas bahwa apoteker adalah tenaga kesehatan yang secara profesional mempunyai martabat luhur dan sumpah jabatan serta kode etik. Itulah sebabnya, pelaksanaan profesi apoteker seperti yang diatur dalam perundang-undangan harus berorientasi pada pelayanan masyarakat.

Namun demikian, seorang apoteker dalam melaksanakan profesinya dapat berperan sebagai produsen obat atau sebagai leveransir obat yang diproduksi oleh suatu pabrik tertentu. Menurut van der Mijn, hal ini menimbulkan diferensiasi pada profesi 
ini, sehingga apoteker dapat dibedakan dalam tiga kategori, yaitu: ${ }^{3}$ Apoteker di Apotek Umum, Apoteker di Rumah Sakit, dan Apoteker di Industri. Akan tetapi yang secara langsung berhubungan dengan masyarakat adalah Apoteker di Apotek.

Adapun fungsi dari Apoteker pada Apotek yaitu memberikan nasihat mengenai obat kepada dokter, dan memberikan penyuluhan mengenai obat kepada masyarakat. Sedangkan apoteker di Rumah Sakit berfungsi di bidang farmakoterapeutik, dan Apoteker di Industri berfungsi sebagai peneliti dan pengawas obat serta turut berperan dalam produksi.

Didasarkan ketentuan Pasal 39 PP No. 51 Tahun 2009, setiap apoteker yang melakukan pekerjaan kefarmasian wajib memiliki Surat Tanda Registrasi Apoteker (STRA), demikian pula TTK yang wajib memiliki Surat Tanda Registrasi Tenaga Teknis Kefarmasian (STRTTK). Untuk memperoleh STRA, Apoteker harus mengajukan permohonan kepada Komite Farmasi Nasional (KFN) dengan melampirkan persyaratan yang dibutuhkan.

Setiap tenaga kefarmasian yang akan menjalankan pekerjaan kefarmasian wajib memiliki surat izin sesuai tempat tenaga kefarmasian bekerja. Surat izin diterbitkan sesuai dengan tugas dan fungsi apoteker pada tempat kerjanya. Sebagaimana ketentuan Pasal 17 Permenkes No. 889 Tahun 2011 Tentang Registrasi, Izin Praktik, Dan Izin Kerja Tenaga Kefarmasian, surat izin apoteker dimaksud berupa:

1. Surat Izin Praktik Apoteker (SIPA) bagi Apoteker penanggung jawab di fasilitas pelayanan kefarmasian;

2. Surat Izin Praktik Apoteker (SIPA) bagi Apoteker pendamping di fasilitas pelayanan kefarmasian;

3. Surat Izin Kerja Apoteker (SIKA) bagi Apoteker yang melakukan pekerjaan kefarmasian di fasilitas produksi atau fasilitas distribusi/penyaluran.

Dengan demikian, apoteker yang akan bekerja di apotek, baik sebagai penanggung jawab ataupun sebagai pendamping, harus memiliki SIPA. Apabila apoteker memiliki tugas dan fungsi sebagai penanggung jawab apotek, maka yang bersangkutan hanya dapat memiliki 1 (satu) SIPA yang artinya hanya boleh menjadi penanggung jawab di satu apotek saja. Namun apabila tugas dan fungsinya sebagai apoteker pendamping, maka kepada yang bersangkutan diberikan paling banyak 3

\footnotetext{
${ }^{3}$ Van der Mijn dalam Soerjono Soekanto, (1990). Aspek Hukum Apotik Dan Apoteker, Bandung: Mandar Maju, hlm. 32.
} 
(tiga) SIPA sebagai pendamping. Apoteker penanggung jawab dapat bekerja sebagai apoteker pendamping di luar jam kerjanya sebagai apoteker penanggung jawab.

Pada kenyataannya, ketentuan mengenai apoteker di apotek belum dilaksanakan sepenuhnya dan ada apotek yang tidak ada apotekernya, yang ada hanya nama apoteker penanggung jawab yang tercantum pada papan nama apotek. Sedangkan pelayanan obat atau kefarmasian hanya dilaksanakan oleh tenaga teknis kefarmasian tanpa pengawasan seorang apoteker.

Dalam melaksanakan pekerjaan kefarmasian di apotek, salah satu tenaga kesehatan yang paling berhubungan dengan apoteker adalah dokter. Hal ini disebabkan, apoteker adalah eksponen dari bidang obat atau kefarmasian, sedangkan penggunaan obat merupakan salah satu tindakan yang paling sering dilakukan oleh deokter dalam memberikan pelayanan medis, sehingga ada interelasi dan interaksi antara kedua profesi tersebut. Adapun media komunikasi yang digunakan dalam menjalankan pengabdian profesi dokter dan apoteker adalah resep dokter.

\section{Pelayanan Obat dengan Resep Dokter}

Didasarkan rumusan pengertian resep menurut Pasal 1 nomor 10 Peraturan Menteri Kesehatan Republik Indonesia Nomor 9 Tahun 2017 Tentang Apotek, yang dimaksud dengan resep adalah permintaan tertulis dari dokter, dokter gigi, atau dokter hewan kepada Apoteker, baik dalam bentuk kertas maupun elektronik untuk menyediakan dan menyerahkan sediaan farmasi dan/atau alat kesehatan bagi pasien. Penulisan resep merupakan keputusan terapi yang dituangkan dalam bentuk permintaan dari dokter kepada apoteker untuk memberikan obat kepada pasien yang sesuai dengan aturan dosis, cara dan lama pemakaian berdasarkan pertimbangan medis. ${ }^{4}$

Kenyataan menunjukkan bahwa, sebuah resep mempunyai arti yang lebih besar dari yang disebut di atas, karena merupakan perwujudan akhir dari kompetensi, pengetahuan dan keahlian dokter dalam menerapkan pengetahuannya di bidang farmakologi dan terapi. Sebab, seorang dokter yang menulis resep, pada dasarnya harus mengetahui mengenai penyerapan dan reaksi obat dalam tubuh, ekskresi obat,

\footnotetext{
${ }^{4}$ Moh. Anief, (2005). Farmasetika, Yogyakarta: Gadjah Mada University Press, hlm. 36.
} 
toksikologi, serta penentuan dosis regimen yang rasional bagi pasien secara individual. Resep ini merupakan perwujudan hubungan profesi antara dokter dan apoteker.

Dari ketentuan di atas juga diketahui bahwa resep hanya boleh diberikan oleh dokter, dokter gigi, dan dokter hewan sesuai dengan kompetensi dan kewenangannya. Oleh karena itu, seorang dokter hewan hanya boleh menuliskan resep untuk keperluan hewan semata-mata. Begitu pula dengan dokter gigi, yang hanya boleh memberikan resep terkait dengan hal-hal yang berkaitan dengan penyakit gigi dan mulut.

Dengan demikian, jika pelayanan obat resep dokter dilakukan oleh seorang tenaga teknis kefarmasian, maka harus dilakukan di bawah pengawasan apoteker. Selain itu, karena resep dokter merupakan media komunikasi profesional yang digunakan dalam hubungan antara dokter dengan apoteker, maka timbul kewajiban dari dokter antara lain menulis resep dengan jelas dan lengkap agar dapat dibaca oleh apoteker. Hal ini penting artinya baik demi kepentingan pasien ataupun untuk memudahkan pelaksanaan pekerjaan pelayanan kefarmasian di apotek.

Dari pengamatan penulis, selain banyak ditemukannya pelayanan resep dokter oleh tenaga teknis kefarmasian, juga apoteker bekerja pada pemilik apotek swasta sehingga apotek lebih tampak sebagai aktivitas bisnis daripada tempat aktivitas apoteker.

Resep dapat dikatakan sah atau resmi dan dilayani oleh apotek apabila memenuhi syarat tertentu yang ditentukan oleh perundang-undangan yang berlaku. Didasarkan Pasal 2 Peraturan Menteri Kesehatan Nomor 280/Men.Kes/SK/V/1981, maka hal-hal yang harus dimuat dalam resep adalah:

1. Nama, alamat, nomor izin praktik dokter, dokter gigi, dokter hewan; dan dapat pula dilengkapi dengan nomor telepon, jam dan hari praktik.

2. Tanggal penulisan resep oleh dokter

3. Nama setiap obat atau komposisi obat (setiap jenis atau bahan dan jumlahnya, cara pembuatan atau bentuk sediaan yang dikehendaki), dan aturan pemakaian obat oleh penderita.

4. Tanda R/sebagai singkatan dari Recipe (yang berarti dapat diambil) harus ditulis pada bagian kiri setiap penulisan resep.

5. Tanda tangan atau paraf dokter penulis resep, sesuai dengan peraturan perundangundangan yang berlaku, karena hal ini yang menjadikan resep otentik. Untuk resep 
obat suntik dari golongan narkotika harus dibubuhi oleh tanda tangan lengkap dari dokter, dan tidak cukup dengan paraf saja.

6. Nama penderita di belakang kata pro (merupakan identifikasi penderita, dan sebaiknya dilengkapi dengan alamat agar memudahkan penelusuran apabila terjadi sesuatu dengan obat yang diberikan pada penderita, serta umur terlebih jika penderitanya seorang anak agar dapat dilakukan pengecekan dosis).

7. Jika penderitanya hewan, maka dalam resep dokter hewan harus dicantumkan jenis hewan dan nama serta alamat pemiliknya.

8. Tanda seru dan paraf dokter untuk resep yang mengandung obat dengan jumlah yang melebihi dosis.

Didasarkan Pasal 21 Permenkes Nomor 9 Tahun 2017 Tentang Apotek, yang menyatakan bahwa:

“(1) Apoteker wajib melayani Resep sesuai dengan tanggung jawab dan keahlian profesinya yang dilandasi pada kepentingan masyarakat.

(2) Dalam hal obat yang diresepkan terdapat obat merek dagang, maka Apoteker dapat mengganti obat merek dagang dengan obat generik yang sama komponen aktifnya atau obat merek dagang lain atas persetujuan dokter dan/atau pasien.

(3) Dalam hal obat yang diresepkan tidak tersedia di Apotek atau pasien tidak mampu menebus obat yang tertulis di dalam Resep, Apoteker dapat mengganti obat setelah berkonsultasi dengan dokter penulis Resep untuk pemilihan obat lain.

(4) Apabila Apoteker menganggap penulisan Resep terdapat kekeliruan atau tidak tepat, Apoteker harus memberitahukan kepada dokter penulis Resep.

(5) Apabila dokter penulis Resep sebagaimana dimaksud pada ayat (4) tetap pada pendiriannya, maka Apoteker tetap memberikan pelayanan sesuai dengan Resep dengan memberikan catatan dalam Resep bahwa dokter sesuai dengan pendiriannya."

Apabila kewajiban dalam pasal ini dihubungkan dengan ketentuan hukum perikatan dalam buku III KUH Perdata, jelas bahwa kewajiban atas diri apoteker ini timbul dari ketentuan perundang-undangan. Sedangkan, dihubungkan dengan Pasal 27 No. 36 Tahun 2009 Tentang Kesehatan, jika kewajiban ini dipenuhi oleh apoteker, maka selaku tenaga kesehatan yang melaksanakan tugas sesuai dengan profesinya serta 
didasarkan keahlian dan kewenangannya, maka apoteker mendapat pelindungan hukum.

Dilihat dari pihak pemberi pelayanannya, maka hubungan antara apoteker selaku pemberi pelayanan obat dan pasien (konsumen) selaku penerima pelayanan obat, maka hubungan ini merupakan hubungan pemberian jasa dalam aktivitas profesional. Hubungan ini harus didasarkan atas kepercayaan dari pasien bahwa apoteker sebagai pihak pemberi jasa pelayanan obat atau kefarmasian akan memberikan pelayanan terbaik sesuai kode etik profesinya. Lain halnya dengan hubungan antara penjual dan pembeli selaku konsumen biasa (tanpa resep), sebab konsumen dapat memilih barang atau jasa yang dibutuhkannya dan penjual memberikan barang atau jasa sesuai yang diminta oleh konsumen. Jika ada kekurangjelasan mengenai barang atau jasa yang diminta maka penjual dapat langsung menanyakan kepada konsumen. Artinya, konsumen berhak memilih obyek yaitu barang atau jasa sesuai keinginannya dan juga berhak membatalkan apabila ada kekuarangan atas barang atau jasa yang diberikan penjual.

Di dalam hubungan pemberian jasa dalam aktivitas profesional antara apoteker dan pasien, yang menjadi obyek adalah obat yang mempunyai nilai materiil. Tetapi, mengingat bahwa fungsi apotek sebagai tempat pengabdian apoteker, maka obat juga merupakan barang yang mempunyai fungsi sosial.

Selain itu, dilihat dari kewajiban apoteker untuk memberikan informasi yang berkaitan dengan penggunaan obat kepada pasien di samping kewajibannya untuk memberikan pelayanan resep obat, maka hal ini merupakan salah satu kewajiban dalam aktivitas profesionalnya. Seperti halnya hal pasien untuk memperoleh informasi dalam hubungan pelayanan medis dengan dokter, maka pasien juga mempunyai hak atas informasi dari apoteker dalam hubungan pelayanan obat di apotek.

Oleh karena itu, jika dimungkinkan sebaiknya dilakukan komunikasi dengan pasien atau pembawa resep mengenai isi resep yang bersangkutan sehubungan dengan kewajiban informasi termaksud. Untuk itu, setelah resep dilayani yaitu pada waktu penyerahan obat, apoteker atau tenaga teknis kefarmasian wajib memberi informasi mengenai penggunaan obat dengan jelas agar timbul kepatuhan pasien pasien terhadap petunjuk penggunaannya, termasuk juga mengenai cara penyimpanan obat secara benar sehingga menghindarkan pasien dari bahaya kerusakan obat. Bahkan, dalam keadaan tertentu, perlu juga diinformasikan mengenai cara mengatasi efek samping 
obat untuk menjamin keamanan pasien. Kewajiban ini merupakan tanggung jawab apoteker yang ada dalam rumusan pekerjaan keprofesian apoteker di apotek. Dalam melaksanakan praktik pelayanan kefarmasian, apoteker memiliki kewajiban untuk: (a) menjamin pelayanan pemberian obat kepada pasien dengan penuh tanggung jawab sesuai dengan ketentuan yang berlaku; (b) memelihara dan melindungi sediaan farmasi dari pengaruh cuaca, temperatur, bencana alam, serangga, dan lain - lain yang dapat menyebabkan menurunnya kualitas obat; (c) menjaga kerahasiaan pasien; (d) menjaga kebersihan lingkungan apotek; (e) memberikan konseling dan residensial; (f) memberikan informasi yang benar mengenai cara penggunaan obat, efek samping, dan kontraindikasi obat; (g) melakukan skrining resep; dan (h) menjaga mutu layanan. ${ }^{5}$

Dalam melaksanakan kewajibannya, seorang apoteker dituntut untuk bertanggung jawab terhadap terapi obat agar dapat tercapai hasil yang optimal untuk meningkatkan kualitas hidup pasien, hal ini merupakan konsep dari pelayanan kefarmasian. Namun, kenyataannya kewajiban sebagaimana diuraikan di atas tidak selalu dapat dilaksanakan atau tidak seluruhnya terpenuhi, karena ada berbagai hambatan dalam pelaksanaannya, yaitu baik yang bersumber dari kelompok profesi itu sendiri ataupun yang bersumber dari dalam masyarakat sebagai konsumen.

Kemudian, di dalam ayat 4 Pasal 21 Permenkes Nomor 9 Tahun 2017 dinyatakan bahwa apabila apoteker menganggap dalam resep terdapat kekeliruan atau penulisan yang tidak tepat, maka harus diberitahukan kepada dokter penulis resep. Jika dokter penulis resep karena pertimbangan tertentu merasa tidak ada kekeliruan termaksud, maka apoteker wajib memberikan catatan pada resep tersebut bahwa dokter tetap pada pendiriannya. Hal ini berarti, segala akibat yang terjadi menjadi tanggung jawab dokter yang bersangkutan. Dalam praktik, hal inipun sulit dilaksanakan, karena berbagai faktor antara lain tidak semua tempat praktik dokter dapat dihubungi dan dokter tidak hanya berpraktik di satu tempat. Lagipula, dalam hal dokter penulis resep tidak dapat dihubungi, maka biasanya penyerahan obat dapat ditunda.

Di dalam Pasal 22 peraturan tersebut di atas, juga diatur mengenai salinan resep. Salinan resep dapat dibuat dan harus disahkan oleh apoteker. Kemudian dalam Pasal 23, resep harus disimpan dengan baik di apotek paling singkat 5 (lima) tahun. Selain itu, resep atau Salinan resep hanya boleh diperlihatkan kepada dokter penulis resep, pasien yang

\footnotetext{
${ }^{5}$ Alexandra Indriati Dewi, (2008). Etika dan Hukum Kesehatan, Yogyakarta: Pustaka Book Publisher, hlm. 149-150.
} 
bersangkutan atau yang merawat pasien, petugas kesehatan atau petugas lain yang berwenang sesuai ketentuan menurut peraturan perundang-undangan.

Di samping itu, ada hal-hal yang juga harus diperhatikan oleh apoteker dalam memberikan pelayanan obat di apotek. Antara lain, apoteker harus mendahulukan resep yang bertanda "segera", "cito", "staten", dan "urgen" pada bagian kanan atas, karena resep tersebut menunjukkan bahwa pasien memerukan pengobatan segera. Seorang apoteker tidak boleh mengulang penyerahan obat atas dasar resep yang sama, apabila pada resep yang asli diberi tanda "ni", "neiteratur", atau "tidak boleh diulang". Hal ini juga berlaku bagi resep yang mengandung narkotika atau obat lain yang ditetapkan oleh Menteri melalui Direktur Jenderal ditetapkan sebagai obat yang tidak boleh diulang tanpa resep baru.

\section{Tanggung Jawab Apoteker dalam Pelayanan Resep Obat}

Apotek adalah tempat pengabdian apoteker sebagai tenaga kesehatan profesional di bidang pelayanan obat atau kefarmasian. Berarti, dalam kegiatan pelayanan yang dilakukan oleh apoteker dapat ditemukan ciri-ciri minimal profesi, yaitu: ${ }^{6}$

1. Profesi merupakan suatu pekerjaan berkedudukan tinggi yang terdiri dari para ahli yang terampil untuk menerapkan peranan khusus dalam masyarakat.

2. Suatu profesi mempunyai kompetensi secara eksklusif terhadap pengetahuan dan keterampilan tertentu yang sangat penting bagi masyarakat maupun klien.

3. Didasarkan pendidikan yang intensif dan disiplin tertentu, mengembangkan suatu taraf solidaritas dan eksklusivitas tertentu.

4. Berdasarkan penguasaan pengetahuan dan keterampilan maupun tanggung jawabnya untuk mempertahankan kehormatan dan pengembangannya, maka profesi mampu mengembangkan etik tersendiri dan menilai kualitas pekerjaan.

5. Profesi cenderung mengabaikan pengendalian dari masyarakat ataupun kliennya.

6. Profesi dipengaruhi oleh masyarakat, kelompok kepentingan tertentu maupun organisasi profesional lainnya, terutama dari segi pengakuan terhadap kemandiriannya.

Apoteker sebagai pengemban profesi dikenal oleh masyarakat melalui kemampuan dan keterampilannya yang khas, yaitu meracik obat menjadi obat jadi yang

\footnotetext{
${ }^{6}$ Veronica Komalawati, (2002). Peranan Informed Consent dalam Transaksi Terapeutik: Suatu Tinjauan Yuridis, Bandung: Citra Aditya Bakti. hlm. 18.
} 
siap digunakan oleh penderita. Obat bukan merupakan barang dagangan biasa, melainkan mempunyai fungsi sosial. Lagipula, obat yang digunakan secara rasional merupakan salah satu faktor yang sangat penting dalam menentukan keberhasilan upaya pelayanan kesehatan. Oleh karena itu, obat termasuk obat jadi dan bahan baku obat harus dikendalikan penggunaannya secara ketat agar tidak disalahgunakan, atau digunakan secara salah. Untuk itu, pengadaan, pengaturan dan pengawasan obat, merupakan salah satu upaya pokok di bidang kesehatan.

Namun, kenyataannya kegiatan profesi kefarmasian khususnya di apotek juga merupakan kegiatan bisnis. Hal ini timbul seiring dengan perkembangan teknologi pembuatan atau peracikan obat, sehingga obat sudah dalam bentuk obat jadi yang diproduksi oleh industri farmasi. Padahal, ada perbedaan antara kegiatan profesi di bidang kesehatan dengan kegiatan bisnis. Orientasi profesi lebih banyak diarahkan ke masyarakat, sedangkan oriantasi bisnis diarahkan pada keuntungan materiel yang maksimal. Pada profesi, kepercayaan masyarakat tertuju pada pemberi jasa, sedangkan pada bisnis kepercayaan masyarakat tertuju pada obyek yang menjadi tolok ukur. Selain itu, etik profesi berbeda dengan etik bisnis.

Jika dilihat dari ciri profesi yang dikemukakan di atas, maka bertitik tolak dari kewenangan dan tanggung jawabnya guna mempertahankan kehormatan dan pengembangannya sebagai profesional, profesi apoteker harus memiliki kode etik sendiri yang mendukung pelaksanaan profesi menurut standar profesinya. Dalam melaksanakan pelayanan kefarmasian, seorang apoteker harus memenuhi ketentuan kode etik. Kode etik adalah panduan sikap dan perilaku tenaga profesi dalam menjalankan profesinya, sebagai aturan norma yang menjadi ikatan moral profesi. Kode etik apoteker merupakan salah satu pedoman untuk membatasi, mengatur, dan sebagai petunjuk bagi farmasis dalam menjalankan profesinya secara baik dan benar serta tidak melakukan perbuatan tercela.

Didasarkan UU No. 36 tahun 2009 pasal 24 ayat 2, ketentuan mengenai kode etik diatur oleh organisasi profesi. Kode etik dibuat oleh organisasi profesi dan digunakan sebagai pedoman seseorang dalam menjalankan profesinya, maka segala bentuk pelanggaran kode etik yang terjadi merupakan tanggung jawab dan peran organisasi profesi dalam menjatuhkan sanksi-sanksinya. Kode Etik Apoteker terbaru nomor 006/2009 disahkan pada tanggal 8 Desember 2009 yang merupakan hasil keputusan Kongres Nasional XVIII ISFI tahun 2009. Kode etik apoteker dibagi menjadi tiga bagian 
yaitu kewajiban apoteker terhadap masyarakat, rekan sejawat, dan rekan profesi kesehatan yang lain.

Di dalam Kode Etik Apoteker Bab V ayat 15 disebutkan, bahwa seorang apoteker harus bersungguh-sungguh menghayati dan mengamalkan Kode Etik Apoteker Indonesia dalam menjalankan tugas kefarmasiannya sehari-hari. Apabila seorang apoteker baik dengan sengaja maupun tak sengaja melanggar atau tidak mematuhi Kode Etik Apoteker Indonesia, maka dia wajib mengakui dan menerima sanksi dari pemerintah, ikatan/organisasi profesi farmasi yang menanganinya (Ikatan Apoteker Indonesia) dan mempertanggungjawabkannya kepada Tuhan Yang Maha Esa.

Sehubungan dengan itu, dalam Pasal 24 ayat 1 UU No. 36 Tahun 2009 ditegaskan, bahwa tenaga kesehatan dalam melakukan tugasnya berkewajiban untuk memenuhi ketentuan kode etik, standar profesi, hak pengguna pelayanan kesehatan, standar pelayanan, dan standar prosedur operasional. Bahkan didasarkan Pasal 58 ayat 1, jika kesalahan atau kelalaian itu menimbulkan kerugian, maka tenaga kesehatan yang bersangkutan berkewajiban membayar ganti kerugian. Pelaksanaan penggantian kerugian itu didasarkan pada ketentuan perundang-undangan yang berlaku.

Adapun dasar tuntutan ganti kerugian karena kesalahan atau kelalaian menurut ketentuan hukum yang berlaku adalah perbuatan melawan hukum sebagaimana diatur dalam Pasal 1365 - 1367 KUHPerdata. Dalam kaitan dengan sebab timbulnya kesalahan pemberian obat yang tidak sesuai dengan resep dokter, standar profesi merupakan tolok ukur untuk menilai terjadinya kesalahan dalam pelayanan resep yang melanggar etik profesi apoteker.

Pekerjaan keprofesian apoteker di apotek merupakan suatu rangkaian kegiatan berdasarkan keilmuan, tanggung jawab, dan etik profesi, yang meliputi:

1. Menyiapkan sediaan obat/farmasi sesuai permintaan dokter, dokter gigi, dokter hewan, atau profesi lain yang memiliki wewenang;

2. Menyiapkan sediaan obat/farmasi atas permintaan penderita, sesuai dengan ketentuan peraturan dan perundang-undangan obat/farmasi;

3. Menetapkan keabsahan obat/bahan farmasi sebagai sediaan-jadi atau bahan baku yang diperlukan dalam pembuatan atau peracikan obat bagi seorang penderita, berdasarkan ilmu kefarmasian yang dimilikinya;

4. Menetapkan keamanan obat dan campuran obat/bahan farmasi yang akan diberikan kepada penderita berdasarkan keabsahan ilmu kefarmasian; 
5. memberikan penjelasan kepada penderita mengenai segala sesuatu tentang obat/racikan obat berdasarkan resep dokter, dokter gigi, dokter hewan dan bahan farmasi sehingga menjamin efek farmakologinya yang optimal;

6. menyediakan obat/bahan farmasi yang diperlukan untuk melangsungkan pekerjaan keprofesiannya berdasarkan kepada mutu farmasetik;

7. menyiapkan dirinya sebagai sumber informasi bagi sejawat profesi kesehatan lain, maupun masyarakat tentang ihwal obat/bahan farmasi berdasarkan keilmuan yang dimilikinya dengan penuh tanggung jawab.

Dalam prakteknya, kesalahan pemberian obat di apotek seringkali terjadi karena penyimpangan dalam pekerjaan apoteker. Setiap kemungkinan rangkaian penyimpangan dalam rangkaian pekerjaan apoteker dapat terlepas dari kemungkinan kesalahan yang dilakukan dokter dalam mendiagnosa, memilih dan menuliskan nama obat serta menentukan tinggi rendahnya dosis obat untuk pasien yang bersangkutan. Sebab jumlah pelaku dalam apotek yaitu petugas apotek juga dapat menjadi penyebab timbulnya kesalahan pemberian obat.

Apabila pada jam kerja apotek banyak menerima resep, sedangkan petugas apotek tidak mencukupi untuk memberikan pelayanan, maka besar kemungkinan petugas apotek terburu-buru karena ingin segera memenuhi pelayanan yang dibutuhkan. Di samping itu, persediaan peralatan yang ada di apotek untuk membuat, mengolah, meracik, mengubah bentuk, mencampur, dan menyimpan obat atau bahan obat kurang memadai, sehingga memungkinkan terjadinya kesalahan pelayanan obat kepada pasien. Faktor penyebab timbulnya kesalahan pemberian obat di apotek, selain dilakukan oleh apoteker ataupun tenaga teknis kefarmasian, juga oleh dokter dan pasien. Dokter dapat disebut sebagai salah satu faktor penyebab timbulnya kesalahan dalam pelayanan obat, karena biasanya tulisan resep yang dibuat dokter sulit untuk dibaca oleh petugas apotek.

Demikian juga, pasien dapat menjadi salah satu faktor penyebab timbulnya kesalahan dalam pelayanan obat. Berawal dari kepercayaan pasien sebagai penderita terhadap dokter bahwa dokter akan melakukan upaya bagi kesembuhan dirinya. Salah satu tindakan terapeutik yang paling sering dilakukan oleh dokter adalah pemberian resep obat yang harus ditukar/dibeli di apotek. Apotek yang melayani resep memiliki petugas yang terbatas, sedangkan resep yang harus dilayani cukup banyak. Dalam situasi yang demikian, pasien ataupun keluarga pasien yang membawa resep ke apotek, 
merasa terlalu lama menunggu sehingga berulang kali menanyakan kepada petugas apotek "apakah obatnya sudah selesai dikerjakan". Dengan demikian, apabila petugas apotek tidak/kurang berhati-hati, maka besar kemungkinannya terjadi kesalahan penyerahan obat. Terlebih jika digunakan nomor pengambilan obat, maka nomor pengambilan perlu dikontrol kesesuaiannya dengan nomor yang diterakan pada resep. Selanjutnya, petugas apotek perlu memeriksa apakah obat yang diterima sesuai dengan yang tertulis dalam resep. Sebab dalam praktek, biasanya dokter memberikan resep kepada pasien disertai petunjuk tentang macam obat. Khususnya, obat tertentu yang penggunaannya harus dilakukan secara khusus, misalnya tidak diminum. Untuk itu, petugas harus secara langsung memberitahukan kepada pasien atau keluarganya sekalipun petunjuk penggunaan sudah tercantum dalam etiket obat. Kemungkinannya, pemberitahuan itu kurang diperhatikan oleh pasien dan petugas apotek hanya memberi penjelasan secara sepintas lalu, maka penggunaan obat yang seharusnya justru dilakukan sebaliknya.

Akibat kesalahan pemberian obat, jika dilihat dari kaitan antara obat dan karakteristik obat adalah "tidak tercapainya kesembuhan pasien". Sedangkan efek sampingnya antara lain, keracunan atau berubahnya perilaku pasien dewasa menjadi seperti anak kecil. Bahkan, yang paling fatal adalah jika mengakibatkan kematian pasien. Sebab efek obat yang salah diberikan, dapat mengakibatkan semakin parahnya penyakit pasien dan kemudian meninggal karena kondisi jantung dan organ tubuh lainnya tidak dapat menerima efek obat yang salah diberikan itu.

Dengan demikian, akibat pemberian obat yang tidak sesuai dengan resep dokter, pada dasarnya merugikan baik pasien dan atau keluarga pasien, baik materiil maupun immateriil. Kerugian materiil dapat berupa biaya yang harus dikeluarkan untuk pengobatan pasien, sedangkan kerugian immateriil tidak dapat dinilai dan diukur dengan kebendaan, misalnya; kehilangan kenikmatan atas kesembuhan yang seharusnya diterima oleh pasien, dan kebahagiaan yang dirasakan oleh keluarganya.

Didasarkan uraian di atas, bahwa kesalahan dalam pelayanan resep dokter di apotek yang paling banyak terjadi yaitu penyimpangan dalam rangkaian pekerjaan apoteker. Penyimpangan termaksud dapat berupa: kesalahan membaca resep dokter, kesalahan pemeriksaan dan penetapan campuran komponen obat di dalam resep, kesalahan penyiapan catatan tentang cara yang baik dalam menyiapkan obat/meracik obat, kesalahan membungkus atau mengemas obat atau racikan obat ke dalam wadah 
yang seharusnya sesuai dan memenuhi syarat wadah secara farmasetik, kesalahan menentukan label yang tepat yaitu berisi instruksi untuk penderita, dan kesalahan penjelasan tentang cara penggunaan obat kepada penderita atau pembawa resep.

Selain itu, telah ditegaskan pula dalam Pasal 1 Peraturan Pemerintah RI Nomor 51 Tahun 2009, bahwa apotek adalah sarana pelayanan kefarmasian tempat dilakukan praktek kefarmasian oleh Apoteker yang telah mengucapkan sumpah jabatan. Dengan demikian, jika apoteker melakukan penyimpangan dalam rangkaian pekerjaannya berarti telah dilakukan kesalahan dalam menjalankan profesi atau kesalahan profesional oleh apoteker atau malpraktik. Adapun pedoman yang digunakan untuk menilai atau menentukan adanya kesalahan tersebut adalah standar profesi Apoteker yang menyangkut pekerjaan keprofesian apoteker di apotek khususnya dalam pelayanan obat berdasarkan resep dokter (pelayanan resep dokter).

Jadi, istilah yang dapat digunakan untuk kesalahan profesional dalam pelayanan obat atau perilaku menyimpang dari pelayan obat atau "the pharmaceutical provider malpractice" atau "the drug provider malpractice". Sehubungan dengan itu, dikemukakan oleh Hoekema, bahwa akibat dilakukannya kesalahan profesi, terutama akan merusak kepercayaan terhadap profesi kesehatan, merusak nama baik kelompok profesi dan lebih lagi nama baik dari yang menggunakan jasa profesi tersebut. ${ }^{7}$

Didasarkan pada ketentuan di dalam Pasal 58 Undang Undang Nomor 36 Tahun 2009 yang menyatakan bahwa "Setiap orang berhak menuntut ganti rugi terhadap seseorang, tenaga kesehatan, dan/atau penyelenggara kesehatan yang menimbulkan kerugian akibat kesalahan atau kelalaian dalam pelayanan kesehatan yang diterimanya", maka apoteker bertanggung jawab atas kesalahan atau kelalaiannya dalam menjalankan profesinya. Ketentuan ini merupakan suatu upaya untuk memberikan perlindungan bagi setiap orang atas suatu akibat yang timbul, baik fisik maupun non fisik karena kesalahan atau kelalaian tenaga kesehatan, termasuk apoteker. Kerugian fisik yang dimaksudkan adalah hilangnya atau tidak berfungsinya seluruh atau sebagian organ tubuh, sedangkan kerugian non fisik berkaitan dengan martabat seseorang, yaitu kehormatan dan nama baiknya. Sedangkan mengenai tanggung jawab hukum dalam hal terjadinya kesalahan di dalam Buku III KUHPerdata diatur dalam Pasal 1365, 1366, dan 1367 KUHPerdata.

\footnotetext{
${ }_{7}^{7}$ Hoekema dalam Soekanto S, (1983). Aspek Hukum dan Etika Kedokteran, Jakarta: Grafiti Press. hlm. 44.
} 
Tanggung jawab hukum karena kesalahan dalam ketiga pasal tersebut, merupakan bentuk klasik pertanggungjawaban perdata yang didasarkan tiga prinsip, yaitu:

1. Setiap tindakan yang menimbulkan kerugian atas diri orang lain, berarti bahwa orang yang melakukannya harus membayar kompensasi sebagai pertanggungjawaban kerugian (Ps. 1365). Didasarkan prinsip ini, untuk mempertanggungjawabkan kesalahan dalam pelayanan resep dokter di apotek, maka unsur-unsur-unsur yang harus dipenuhi, yaitu: tindakan atau perbuatannya, kerugiannya, kesalahannya, dan hubungan antara tindakan dan kerugian. Dalam hal tindakan atau perbuatan, apakah tindakan itu termasuk kegiatan profesional yang termasuk fungsi dan tugas apoteker. Dalam hal kerugian, apakah ada pihak yang benar-benar menderita kerugian. Dalam hal kesalahan, siapakah yang melakukan kesalahan itu. Dalam hubungan antara tindakan dan kerugian, apakah dapat dibuktikan adanya hubungan kausal antara tindakan dan kerugian yang timbul. Apabila, hal-hal tersebut telah terpenuhi dan terbukti, berarti telah terjadi kesalahan sehingga pelakunya dapat dituntut untuk membayar ganti kerugian.

2. Seseorang harus bertanggung jawab tidak hanya atas kerugian karena kesalahan dari tindakannya yang disengaja, melainkan juga dari kelalaiannya atau kurang berhatihati (Pasal 1366). Didasarkan prinsip ini, maka apoteker tidak hanya bertanggung jawab atas kerugian yang timbul dari tindakan atau perbuatannya, melainkan juga karena tidak bertindak atau berbuat sesuatu akibat kelalaian atau kurang berhatihati.

3. Seorang harus bertanggung jawab tidak hanya atas kerugian karena kesalahan dari tindakan atau perbuatannya sendiri, melainkan juga dari tindakan atau perbuatan orang lain yang berada di bawah pengawasannya. Didasarkan prinsip ini, apoteker bertanggung jawab atas tindakan tenaga teknis kefarmasian dan petugas lainnya di apotek yang terlibat dalam pelayanan obat atau kefarmasian yang dilakukan di apotek. Dalam hal pelayanan obat didasarkan resep dokter, maka jika timbul kerugian pada penderita karena pemberian obat yang tidak sesuai dengan isi resep walaupun penggantian atau perubahannya telah disepakati oleh pembawa resep, tetap apoteker yang bertanggung jawab.

Sehubungan dengan pembuktian adanya kesalahan, maka dalam hal ini harus dibuktikan adanya penyimpangan dalam rangkaian pekerjaan apoteker. Didasarkan 
prinsip hukum mengenai pembuktian yang terkandung dalam Pasal 1865 KUHPerdata yang menyatakan bahwa orang yang menuntut suatu hak atau membantah hak orang lain, berkewajiban membuktikannya. Berarti, pihak penderita yang merasa dirugikan harus membuktikan adanya kesalahan profesional berupa penyimpangan terhadap rangkaian pekerjaan apoteker. Hal ini sulit untuk dilakukan, jika tidak cukup informasi untuk membuktikannya. Oleh karena itu, insan profesi apoteker harus memiliki kesadaran hukum dalam menjalankan tugas profesionalnya. Sedangkan hukum, memungkinkan dilakukannya cara pembuktian sebaliknya yang dibebankan kepada pihak lawan (apoteker).

Selain itu, di dalam Pasal 11 Peraturan Menteri Kesehatan No. 9 Tahun 2017 dinyatakan bahwa apoteker pemegang SIA dalam menyelenggarakan apotek dapat dibantu oleh apoteker lain, tenaga teknis kefarmasian dan/atau tenaga administrasi. Dalam penjelasan Pasal 51 Ayat 3 PP No. 51 Tahun 2009 ditegaskan bahwa “Dalam hal Apoteker dibantu oleh Tenaga Teknis Kefarmasian, pelaksanaan pelayanan Kefarmasian tetap dilakukan oleh Apoteker dan tanggung jawab tetap berada di tangan Apoteker". Itulah sebabnya, dinyatakan bahwa Apoteker bertanggung jawab atas kesalahan tenaga teknis kefarmasian.

Namun demikian, tidak semua perbuatan tenaga teknis kefarmasian khususnya mengenai pekerjaan kefarmasian menjadi tanggung jawab apoteker, karena diperlukan adanya hubungan tertentu antara perbuatan dari tenaga teknis kefarmasian dengan hubungan kerja. Artinya, apoteker bertanggung jawab atas pekerjaan kefarmasian yang dilakukan tenaga teknis kefarmasian sepanjang perbuatan itu dilakukan selama jam kerja.

Oleh karena di dalam kenyataannya, bahwa tuntutan ganti kerugian yang dibebankan kepada apoteker akibat tindakan atau perbuatan orang-orang yang berada di bawah pengawasannya itu dirasakan sangat berat, sehingga jika sepenuhnya dibebankan kepadanya dirasakan tidak adil. Itulah sebabnya, sekalipun pembayaran ganti kerugian sepenuhnya dibebankan kepada apoteker, namun kemudian secara intern setelah perkaranya diputus, apoteker meminta pengembalian pembayaran sebagian ganti kerugian yang menjadi tanggungan tenaga teknis kefarmasian yang melakukan kesalahan tersebut.

Dalam hal pasien meninggal dunia, maka tuntutannya didasarkan Pasal 1365 jo. 1370 KUHPerdata; dan jika pasien menderita cacat badan atau luka berat tuntutannya 
didasarkan Pasal 1365 jo. 1371 KUHPerdata. Jadi, Pasal 1365 KUHPerdata merupakan ketentuan umum, sedangkan Pasal 1370 dan 1371 KUHPerdata adalah ketentuan khusus.

\section{PENUTUP}

Dari uraian di atas dapat diambil kesimpulan sebagai berikut Tugas dan kewenangan apoteker dalam menjalankan pekerjaan kefarmasian adalah dalam pembuatan termasuk pengendalian mutu sediaan farmasi, pengamanan, pengadaan, penyimpanan dan pendistribusian atau penyaluran obat, pengelolaan obat, pelayanan obat atas resep dokter, pelayanan informasi obat, serta pengembangan obat, bahan obat dan obat tradisional.

Resep dokter merupakan perwujudan akhir dari kompetensi, pengetahuan dan keahlian dokter dalam menerapkan pengetahuannya di bidang farmakologi dan terapi. Resep adalah media komunikasi profesional yang digunakan dalam hubungan antara dokter dengan apoteker. Apoteker wajib melayani resep dokter sesuai dengan tanggung jawab dan keahlian profesinya yang dilandasi pada kepentingan masyarakat.

Tanggung jawab apoteker dalam pelayanan obat yang diresepkan dokter adalah harus mengutamakan kebutuhan dan keselamatan pasien. Dasar pertanggungjawaban perdata berupa tuntutan ganti kerugian adalah perbuatan melawan hukum sebagaimana diatur dalam Pasal 1365-1367 KUHPerdata yang diakibatkan oleh kesalahan atau kelalaian apoteker dalam menjalankan pekerjaannya. Pedoman yang digunakan untuk menilai atau menentukan adanya kesalahan atau kelalaian tersebut adalah standar profesi apoteker yang menyangkut pekerjaan keprofesian apoteker di apotek khususnya dalam pelayanan obat berdasarkan resep dokter (pelayanan resep dokter). 


\section{DAFTAR PUSTAKA}

\section{Buku}

Alexandra Indriati Dewi. (2008). Etika dan Hukum Kesehatan. Yogyakarta: Pustaka Book Publisher.

Ali Mashuda. (2012). Paradigma dan Tatanan Baru Praktik Kefarmasian. Bandung: Tiga Maha.

Badan Pimpinan Pusat Ikatan Sarjana Farmasi Indonesia. (1983). Profesi Apoteker. Jakarta. Emma S Surahman. (2011). Konsep Dasar Pelayanan Kefarmasian Berbasiskan Pharmaceutical Care. Bandung: Widya Padjadjaran.

Moh Anief. (2005). Farmasetika. Yogyakarta: Gadjah Mada University Press.

Soerjono Soekanto. (1990). Aspek Hukum Apotik dan Apoteker. Bandung: CV Mandar Maju. . (1983). Aspek Hukum dan Etika Kedokteran. Jakarta: Grafiti Press.

Veronica Komalawati. (2002). Peranan Informed Consent Dalam Transaksi Terapeutik: Suatu Tinjauan Yuridis. Bandung: Citra Aditya Bakti..

\section{Jurnal}

Wendi Muh. Fadli, et.al., (2016). Tanggungjawab Hukum Dokter dan Apoteker dalam Pelayanan Resep, Media Farmasi, Vol. 13, No. 1, Maret Tahun 2016.

\section{Dokumen Lain}

Undang - Undang No. 29 Tahun 2004 Tentang Praktik Kedokteran.

Undang - Undang No. 36 Tahun 2009 Tentang Kesehatan.

Kitab Undang - Undang Hukum Perdata.

Peraturan Pemerintah No. 51 Tahun 2009 Tentang Pekerjaan Kefarmasian.

Peraturan Menteri Kesehatan Republik Indonesia Nomor 9 Tahun 2017 Tentang Apotek.

Peraturan Menteri Kesehatan Republik Indonesia Nomor 73 Tahun 2016 Tentang Standar Pelayanan Kefarmasian di Apotek.

Peraturan Menteri Kesehatan No. 889 Tahun 2011 Tentang Registrasi, Izin Praktik, dan Izin Kerja Tenaga Kefarmasian. 